Kapás Judit*

\title{
Variációk evolúciós megközelítésmódra
}

\author{
Beszámoló az EAEPE 2007. évi konferenciájáról \\ (Porto, 2007. november 1-3.)
}

A European Association for Evolutionary Political Economy ${ }^{1}$ (EAEPE) szokásos éves konferenciájának házigazdája 2007-ben a Portói Egyetem Közgazdaságtudományi Kara volt. Az EAEPE konferenciák a nagyobb szabású európai konferenciák közé tartoznak, Portóba is mintegy 200 kutató jött el. A konferencián elhangzott előadások, követve a sokéves hagyományt, vagy egy-egy EAEPE kutatási terület ${ }^{2}$ felhívásához kapcsolódtak, vagy a konferencia meghirdetett általános témájáról szóltak. Ez alkalommal az Economic growth, development and institutions - lessons for policy and the need for an evolutionary framework of analysis témameghatározás jelentette az általános gondolati keretet.

Az EAEPE tagjait nem annyira a kutatási téma, mint inkább az alkalmazott megközelítés és a hangsúlyok különböztetik meg más közgazdasági kutatóktól. Ezt tanúsította a 2007. évi konferencia is: a témák széles spektrumon mozogtak, de az előadásokban a változás, a dinamika, a fejlődés, a szelekció, a tévedések voltak a kulcskoncepciók. Ezek a koncepciók jelentik az evolúciós megközelítés lényegét, amely sok közgazdasági probléma alaposabb megértését teszi lehetővé.

A három plenáris előadás által elemzett kérdések is jól példázzák a témák sokszínüségét az evolúciós megközelítésmód mellett. Maria Joao Rodrigues, aki a Portói Egyetem professzora és Portugália EU elnöksége alatt a miniszterelnök különtanácsadója volt, a Lisszaboni Agendát vette górcső alá evolúciós megközelítésben. Ezt követően Gerald Silverberg (United Nations University) az innovációs folyamat "fekete dobozát” nyitotta ki, s elemezte az innováció fenomenológiai komplexitását. A záró kulcselőadást Stan Metcalfe (University of Manchester) jegyezte Marshall, Schumpeter and the evolution of capitalism címmel.

A variációk evolúciós megközelítésmódra csak tovább szaporodtak a szekciókban elhangzott előadások során. A bemutatott kutatások nagyobbik része természetesen olyan kérdéskörökkel foglalkozott, amelyek az evolúciós megközelítés természetes területei. Ezek közé tartozik az innováció, az evolúciós közgazdaságtan módszertana, Schumpeter örök-

* Kapás Judit a Debreceni Egyetem Közgazdaságtan tanszékének docense, e-mail címe: judit.kapas@econ.unideb.hu

1 A társaság honlapja: www.eaepe.org

2 Az EAEPE 17 kutatási területen munkacsoportokat hozott létre, ezzel is segítve a párbeszédet az azonos területen dolgozó kutatók között. 
sége vagy a technológiai változás. Ezekkel a kérdésekkel külön-külön több szekció foglalkozott. E hagyományosan evolúciós felségterületek mellett azonban új témák is előtérbe kerültek, amelyek eddig nem tartoztak az evolúciós megközelítés tipikus területei közé. Tekintettel arra, hogy kivitelezhetetlen vállalkozás lenne teljes képet nyújtani a konferencia gazdag programjáról, így az alábbiakban inkább arra teszek kísérletet, hogy az új témákból villantok fel néhányat. A célom ezzel az, hogy felhívjam a figyelmet arra, hogy sokkal több kérdés elemzésében bizonyul hasznosnak az evolúciós szemléletmód, mint azt hagyományosan gondolnánk.

\section{Az egyenlötlenség kérdése}

Az egyenlőtlenség kérdésének egy egész szekciót szenteltek a szervezők, amelyben öt elöadás hangzott el. Az előadások közös jellemzője volt, hogy az egyenlőtlenséget dinamikus folyamatként, s nem állapotként fogták fel. Ennek fényében minden kutató a változások okait kereste. Nem meglepő módon az átmeneti országok különös figyelmet kaptak, az azonban már meglepő tény, hogy a fejletlen országok elemzése hiányzott a palettáról.

Pascal Petit (Université de Paris-Nord), a társaság elnöke előadásában (Inequality and growth regimes - an institutionalist perspective) abból indult ki, hogy az egyenlötlenségnek sok dimenziója létezik, tevékenységi szférák vagy időhorizont szerint is. Az egyenlőtlenség struktúrája, ahogy hangsúlyozta, változik az időben. A változások között ő a figyelmét a növekedési rezsimek által kiváltott egyenlőtlenségekre irányította. Kutatásában azt próbálta elemezni, hogy hogyan lehet egyenlőtlenségi rezsimeket definiálni. Ezt két síkon javasolta. Egyrészt, az új növekedési rezsimek új, másfajta egyenlőtlenségeket hoznak magukkal, másrészt, az egyenlötlenségek mintái országonként is eltérhetnek. Ez utóbbi esetben az egyenlőtlenségi rezsimek a kapitalizmus változatosságának hordozói. Az egyenlőtlenségi rezsimek pontosabb azonosításhoz sokféle, különböző területre és időhorizontra vonatkozó méröszámot használt a fejlett országok esetében. Azt is megvizsgálta, hogy a posztfordista növekedési rezsim vajon tartósan növelte-e az országok közötti egyenlőtlenségeket, vagy az egyenlőtlenség fokozódása csak átmeneti jelenség volt.

Jacek Tomkiewicz (TIGER Intézet, Varsó) a posztszocialista országok esetében vizsgálta az egyenlötlenség növekedését. Megállapította, hogy a tranzíció után a jövedelemegyenlőtlenség fokozódása egyrészt a piaci erők müködésének következménye volt, és ennyiben kedvező változásnak tekinthető: mivel a piacon erős az ösztönzés a munkatermelékenység növelésére, akik ezt megvalósítják, nagyobb jövedelemhez jutnak. Ugyanakkor az egyenlőtlenség növekedésének egy másik része a piaci kudarcokból (monopóliumok) származott. Tomkiewicz az előbbi dilemma kapcsán arra a kérdésre kereste a választ, hogy mennyiben volt az egyenlőtlenség fokozódása az „egészséges” piaci erők következménye és mennyiben a piaci kudarcoké. Elemzésében kiemelt figyelmet szentelt az állam tevékenységének.

Gianluca Grimaldi és Elena Meschi (CSGR, Róma) Mechanisms of inequality in transition economies címü előadása szorosan kapcsolódott lengyel kollégájukéhoz. A két olasz kutató az átmenet utáni egyenlőtlenség fokozódásának okait azonosította. Kvantitatív elemzésük az egyes tényezők hatását külön-külön és együttesen is vizsgálta. Külön választották az EU-hoz csatlakozott országokat és megnézték, hogy a csatlakozás ténye milyen hatással volt az egyenlötlenség mértékére. Kutatásuk arra mutatott rá, hogy a csatlakozó országok képesek voltak fegyelmezettebben végrehajtani intézményeik átalakítását, és ez kisebb egyenlőtlenséghez vezetett, mint a nem csatlakozó országokban. 


\section{Vállalatelmélet}

Bár a vállalatelmélet terén az evolúciós megközelítés Nelson és Winter (1982) nagy hatású könyve óta jelen van, a munkák zöme inkább iparági szinten foglalkozott a vállalattal. A hagyományos vállalatelméleti megközelítés a Coase (1937) által felvetett kérdések - nevezetesen, hogy miért léteznek vállalatok, és mi határozza meg a vállalat határait - megválaszolását igényli. Jan Stoelhorst (University of Amsterdam) a coase-i „miért léteznek vállalatok" kérdést fogalmazta át két alapvetőbb kérdéssé annak érdekében, hogy a vállalat létére evolúciós - történeti választ adhasson.

Az első kérdés arra vonatkozott, hogy az ember miért képes kiterjedt kooperációt fenntartani nem vérségi kapcsolatokban is. Ennek kapcsán az előadó hangsúlyozta, hogy evolúciós szempontból minden egyéni szintet meghaladó kooperáció magyarázatot igényel, mert ha nem lenne valamilyen ellentételező erö, a csoporton belüli verseny lehetetlenné tenné ezt a kooperációt. Ugyanakkor a fenti kérdés megválaszolása a korlátozott racionalitás és az opportunizmus feltevése helyett/mellett másfajta magatartási feltevéseket is feltételez, mint például az altruizmus, a fair magatartás vagy a dominancia elfogadása. Ezek a magatartástípusok ugyanis döntőek a sokszereplős koordinációkban.

A második probléma azzal kapcsolatos, hogy milyen evolúciós pálya mentén fejlödött a társadalmi - gazdasági szervezet olyan irányba, amely végül a vállalat megjelenéséhez vezetett. A kérdések megválaszolásában azt tartotta szem előtt Stoelhorst, hogy az evolúciós megközelítésmódban nem absztrakcióként kell a vállalatot felfogni, hanem fejlődését, változatosságát és magatartását kell megmagyarázni. A fejlődési pályát több feszültség jellemzi. Ezek között a legfontosabb a csoporton belüli és csoportok közötti szelekció. Az előadó szerint az, hogy a vállalat miért képes koordinálni, ennek a feszültségnek a kontextusában érthetö meg.

Tovább folytatva a gondolatmenetet, a kutató kiemelte, hogy ha a vállalat már létrejött, ő maga is ki lesz téve a szelekciónak. Ha a versenyben sikert ér el, az a tagok magatartásának kontextusában érthető csak meg. Ezzel Stoelhorst azt hangsúlyozta, hogy a vállalatnak társadalmi dimenziója van, amit a neoklasszikus vállalatelméletek negligálnak.

\section{Tulajdonosi jogok}

A tulajdonjog problémája az intézményi közgazdaságtan egyik fontos területe, de Portóban több elöadás is elhangzott, amely evolúciós megközelítésben vizsgálta ezt a kérdést. Oliver Weinstein (Université de Paris 13) Institutions, property rights and markets - the case of knowledge markets címmel tartott elöadásában a tulajdonosi jogokat a tudáspiac (technológiapiac) létrejöttének kontextusában vizsgálta.

A tudáspiac a termékpiachoz képest számos eltérő tulajdonságot mutat, amelyek komoly konzekvenciákkal járnak a tulajdonosi jogokra nézve. Ezeken a piacokon a tulajdonosi jogokat a felállított intézmények biztosítják, amelyek egy komplex társadalmi intézményi erőtérben jönnek létre. Ezen intézmények egy része a kodifikálható tudáshoz kapcsolódik, úgy mint a szabadalom, amely a tudás piaci adásvételét is lehetővé teszi. Az intellektuális tulajdonosi jogok pontos definiálása, hangsúlyozta a professzor, jelentősen hat a tudáspiac fejlődésére. Azt is kiemelte, hogy a tudáspiacok kialakulása csak a globalizáció kontextusában érthető meg. 
A tudáspiacon gyakran találkozunk a williamsoni terminológiában (Williamson 1991) hibrideknek ${ }^{3}$ nevezett irányítási struktúrákkal. Ennek kapcsán Weinstein arra hívta fel a figyelmet, hogy ahhoz, hogy a tudáspiac mibenlétét megérthessük, a piaci kapcsolatok természetét is pontosabban meg kell világítanunk.

$\mathrm{Az}$ intellektuális tulajdonosi jogok és a tudáspiac kapcsán az előadó szerint három kérdés érdemel kiemelt figyelmet. Elöször is tekintettel kell lenni arra, hogy a tudás egyedi, de az egyes „tudás egységek” kiegészítik egymást. Másrészt problematikus az egyes „tudás egységek” értékelése. Harmadrészt, az előző kettő okán a tudás „piacosítását” támogató intézmények fontos szerepet játszanak. Ezt követően a professzor e három kérdést két eset kapcsán világította meg - a technológiai piac megjelenése az USA-ban a 19. században és az 1980-as évektől formálódó új tudáspiac és intellektuális tulajdonosi jogi rendszer.

\section{Hivatkozások}

Coase, R. H. (1937): The Nature of the Firm. Economica, 4. évf., 16. sz., 386-405.

Nelson, R. R. - Winter, S. G. (1982): An Evolutionary Theory of Economic Change. Harvard University Press, Cambridge, London.

Williamson, O. E. (1991): Comparative Economic Organization: The Analysis of Discrete Structural Alternatives. Administrative Science Quarterly, 36. sz., 269-296.

\footnotetext{
${ }^{3}$ A hibrid irányítási struktúra a piacra és a vállalatra jellemzö jegyeket ötvözi, minden tulajdonságában köztes értéket mutat a másik kettőhöz képest. Ide sorolhatók a vállalatok közti hosszú távú kapcsolatot jelentő formák (például franchising, stratégiai szövetségek, kutatási megállapodások).
} 